\title{
Possibilities to determine biometric parameters using airborne laser scanning data
}

\author{
Mariya Polyakova*, and Yury Otmakhov \\ Central Siberian Botanical Garden SB RAS, 630090 Novosibirsk, Russia
}

\begin{abstract}
The paper brings forward ways to solve the problem of estimating the trunk diameter using data of airborne laser scanning (LIDAR) relevant for forest inventory. At the first stage of studying, it was defined the regularities of tree height and diameter relations for various species, as well as the coefficients of coupling equations of the significance of "height-diameter" relations based on field data. At the second stage, it was calculated the relations of crown parameters (diameter and volume) and the trunk height and diameter at $1.3 \mathrm{~m}$ level accounting parameters dependent of species. Based on the estimated and LIDAR data, the resulting calculations of tree diameters were made with $83.2 \%$ accuracy. The proposed calculation of the trunk diameter is an important step for further development of an automated algorithm to obtain basic taxation indicators, such as the tree trunk number, height and diameter. The data got by this way can be used for high density forests while cuttings assessment using LIDAR.
\end{abstract}

\section{Introduction}

LIDAR as a relatively affordable modern tool to collect various data at the earth's surface has been widely used to develop and adapt this technique in forest inventory. In contrast to the digital aerial photography, widely used in taxation works, LIDAR is more expensive tool, but the resulted data detail is significantly higher than in aerial photography, in addition, it makes it possible to get both the visible surface of scanned territories or objects (their geometric parameters obtained by direct measurement), for example, tree crowns, and give an opportunity to get data on invisible surfaces (relief).

Scientists have been actively using and improving the interpretation of LIDAR data to simplify and reduce the cost of stand inventory studies recent 10-15 years. Thus, a large number of works are devoted to assessing the species composition based on the forest canopy 3D architectural model (Widlowski et al., 2003; Nikolaev, 2014; Pinto, 2014), and evaluating the forest stock and phytomass (Danilin, 1992).

In addition, the most relevant aspects of the forest taxation is assessing the trunk height and diameter. Attempts of these parameter algorithmic calculations are shown in a number

\footnotetext{
*Corresponding author: otmachov@mail.ru
} 
of studies (Means et al., 2000; Holmgren et al., 2003; Maltamo et al.,2003; Fransson et al., 2004; Holmgren, 2004).

The main problem faced by researchers is the impossibility by LIDAR data to make direct measurements of the trunk diameter at $1.3 \mathrm{~m}$ level of the ground surface (which corresponds to the classical technique of measuring trunk diameters in the field) at a forest stand density of 0.7 and higher. The work objective is to reveal the relationship of the "height-diameter" and " crown diameter - tree diameter" parameters in various tree species to obtain a tool for calculating the trunk diameter by LIDAR data. To solve this goal, the following tasks were set:

1. To make airborne laser scanning of the study area to get biometric data such as stand height; diameter, crown area and volume; species composition.

2. To take accurate biometric indicators of the growing stand in field conditions to apply the data in comparative analysis.

3. To choose algorithms of calculating the trunk diameter at $1.3 \mathrm{~m}$ level for various tree species.

4. To test the empirical and actual data.

\section{Materials and Methods}

\subsection{Object of study}

The study was carried on in the Nefteyugansk Municipal District located in southern Khanty-Mansi Autonomous Okrug (N60.682845; E70.839609). The regional vegetation is differentiated by latitudinal-zonal features and represented by cedar-pine forests with spruce admixture, and birch-aspen grass-moss woods with dark coniferous species impure. Besides, there are dark coniferous spruce and spruce-cedar shrub-green moss forests with fir; in the river valleys - spruce, fir-spruce-cedar and birch forests in combination with willows and swamps. The predominated species composition are made by Siberian cedar (Pinus sibirica) - 56.5\%, common pine (Pinus sylvestris), Siberian spruce (Picea sibirica), and Siberian fir (Abies sibirica) $-24.7 \%$, birch and aspen $-18.8 \%$ of the forest covered area (The scheme ..., 2007).

\subsection{Methods}

10 plots $(\mathrm{S} 1,2, \ldots=50 \times 50 \mathrm{~m}=0.25 \mathrm{ha})$ were laid and marked in the field, their geographical gridding was carried out. The taxation and geobotanical characteristics of each sample plot were made (geobotanical description; age, species, diameter and height of each tree on the plot; species composition and number of undergrowth, etc.). Each tree geographical gridding and cutting areas (plots) dividing into taxational sections (allotments) were fulfilled (Manual on ..., 1993; Minaev et al., 2004).

The classification of laser reflection points based on automated LIDAR data processing was carried out. A digital elevation model (DEM) in the height matrix form was built using the relief class points. A digital surface model (DSP) was created by points belonging to the surface of situation and relief objects. To determine tree heights, DEM was subtracted from DSP followed by searching for local maxima. Thus, the following indicators were obtained for each tree: coordinates, height, crown diameter, its area and volume.

Measuring the height, diameter, quantity and distribution of forest elements was carried out by analytical interpretation of the stand species composition (Anuchin, 1982; Zagreev et al., 1992). The model features of parameter relations in stands obtained by LIDAR data and diameters at breast height were calculated based on regression models (Näslund, 1929). 


\section{Results}

The foundation to calculate tree diameters is the idea of a relationship between the forest stand taxation characteristics ("height-diameter"). To estimate the tree diameter, a regression model of dependencies of calculated taxation parameters and indicators obtained during field studies (tree height and diameter) and LIDAR data (tree height, crown diameter, area, and volume) was created.

\subsection{Calculating the diameter by the tree height}

Two-parameter models are the simplest and most widely used in forest inventory ones of dependence of the tree height on the diameter at breast height. It's to note, that these models show better results than three-parameter models, as they allow avoiding the initial data overfitting. Simple mathematical functions (polynomial, fractional polynomial, exponential, etc.) previously used to describe the "height - diameter" relationship allows getting good results, but with the least reliability.

In many studies, the Näslund equation (Näslund, 1929) has been successfully used as a two-parameter model of the "height-diameter" relationship, which served a base to develop nonlinear models with a mixed effect for forest stands:

$$
h=1.3+\left(\frac{d}{a+b d}\right)^{3}
$$

where, $\mathrm{h}$ - tree height, $\mathrm{m}$; $\mathrm{d}$ - tree diameter at breast height, $\mathrm{cm}$; $\mathrm{a}$ and $\mathrm{b}$ - model parameters (Note: Model parameters are calculated by minimizing the mean square error).

Based on the Neslund equation with known calculated data on the stand height (h) and features of model parameters or coefficients of the coupling equations ( $a$ and $b$ ), a tree diameter at breast height $(\mathrm{d})$ is calculated:

$$
d=\frac{2 a b h-\frac{13 a b}{5}-\sqrt{-\left(a^{2} h+\frac{13 a^{3}}{10}\left(-4 b^{2} h+\frac{26 b^{2}}{5}+4\right)+\left(-2 a b h+\frac{13 a b}{5}\right)^{2}\right.}}{-2 b^{2}+\frac{13 b^{2}}{5}+2}
$$

Table 1. Coefficients of the coupling equations and significance of "height-diameter" relationship calculated by field data

\begin{tabular}{|c|l|c|c|c|c|}
\hline \multirow{2}{*}{ No } & \multirow{2}{*}{ Species } & \multicolumn{2}{|c|}{$\begin{array}{c}\text { Coupling equation } \\
\text { coefficient }\end{array}$} & \multicolumn{2}{c|}{ Coupling closeness } \\
\cline { 3 - 6 } & & $\mathrm{a}$ & $\mathrm{b}$ & $\mathrm{r}$ & $\mathrm{D}$ \\
\hline 1 & Abies sibirica & 1.87 & 0.82 & 0.86 & 0.74 \\
\hline 2 & Betula pubescens & 0.44 & 1.10 & 0.83 & 0.70 \\
\hline 3 & Picea obovata & -0.88 & 1.19 & 0.89 & 0.80 \\
\hline 4 & Pínus sibirica & -0.88 & 1.19 & 0.90 & 0.81 \\
\hline 5 & Pinus sylvestris & 2.09 & 1.26 & 0.94 & 0.88 \\
\hline 6 & Populus tremula & -19.34 & 2.76 & 0.65 & 0.42 \\
\hline
\end{tabular}

Note: $\mathrm{a}$ and $\mathrm{b}$ are model parameters; $\mathrm{r}$ - correlation coefficient; $\mathrm{D}$ - determination coefficient

\subsection{Calculating the diameter by the tree crown volume}

The relationship between the parameters of tree crowns (diameter, volume) with the trunk heights and diameters at breast height is calculated by the formula: 


$$
D c=m_{0}+m_{1} d+m_{2} h+m_{3} d h(3)
$$

where $\mathrm{m} 0, \mathrm{~m} 1, \mathrm{~m} 2, \mathrm{~m} 3$ - parameters dependent of species (Table 2 ); $\mathrm{h}$ - tree height, $\mathrm{m} ; \mathrm{d}-$ trunk diameter at breast height.

Table 2. Model parameters of relationships of tree crown sizes and their heights and diameters at breast height

\begin{tabular}{|c|l|c|c|c|c|}
\hline \multirow{2}{*}{ No } & \multirow{2}{*}{ Species } & \multicolumn{4}{|c|}{ Model coefficients } \\
\cline { 3 - 6 } & & $m_{0}$ & $m_{1}$ & $m_{2}$ & $m_{3}$ \\
\hline 1 & Abies sibirica & 0.865 & 0.751 & 0.283 & -0.007 \\
\hline 2 & Betula pubescens & 1.009 & 0.089 & -0.019 & 0.004 \\
\hline 3 & Picea obovata & 1.321 & 0.207 & -0.008 & 0.002 \\
\hline 4 & Pínus sibírica & 1.108 & 0.623 & 0.209 & 0.003 \\
\hline 5 & Pinus sylvestris & 0.195 & 0.227 & 0.008 & -0.752 \\
\hline 6 & Populus tremula & -0.098 & 0.230 & 0.081 & -0.001 \\
\hline
\end{tabular}

The study notes a close relation of an average tree trunk diameter (d) and crown diameter (Dc), which is linear; it establishes the relation of an average crown diameter and tree diameter for different species (the determination coefficient is $0.5-0.8$ - Table 3), which corresponds to a weak, moderate and strong coupling closeness. Deciduous tree species (birch) and light coniferous (pine) are characterized by narrow and high crowns, while dark coniferous (spruce, fir, cedar) and deciduous (aspen) have a wide vertical crown. Spruce, in turn, has rather high degree of the crown shape plasticity depending on the tree age and growing conditions (Shanin et al. 2016), which is confirmed by the results obtained at the studied area.

Based on the multiple regression model of the relationship of tree diameter and the data got by the remote technique using LIDAR (crown diameter), it is possible to calculate a tree diameter:

$$
d=a+b_{1} \times h+b_{2} \times D_{c}
$$

where $\mathrm{d}$ - diameter at breast height, $\mathrm{cm} ; \mathrm{h}$ - tree height, $\mathrm{m} ; \mathrm{D}_{\mathrm{c}}-$ tree crown diameter, $\mathrm{m} ; \mathrm{R}^{2}$ - determination coefficient charactering the coupling closeness equation; $a, b_{1}, b_{2}$ coefficients of the linear regression equation (Table 3 ).

Table 3. Coefficients of coupling equations and the significance of the "crown diameter - stand diameter" relations calculated by field data

\begin{tabular}{|c|l|c|c|c|c|}
\hline No & \multicolumn{1}{|c|}{ Species } & $R^{2}$ & $a$ & $b_{1}$ & $b_{2}$ \\
\hline 1 & Abies sibirica & 0.8 & -5.37 & 2.03 & 1.89 \\
\hline 2 & Betula pubescens & 0.7 & -5.78 & 0.78 & 2.28 \\
\hline 3 & Picea obovata & 0.8 & 6.23 & 1.28 & 2.13 \\
\hline 4 & Pínus sibírica & 0.8 & -8.32 & 1.09 & 3.02 \\
\hline 5 & Pinus sylvestris & 0.9 & 4.58 & 1.26 & 1.88 \\
\hline 6 & Populus tremula & 0.5 & -3.27 & 0.72 & 2.74 \\
\hline
\end{tabular}

\section{Discussion}

As a study result and analysis of taxation indicators on the test plots and LIDAR data, relations of the "height-diameter" and "diameter of the tree crown-diameter" parameters 
were established. According to the research results, the relation is traced between the average crown diameter and taxation diameter for various breeds (the determination coefficient varies from 0.5 to 0.9 ). The highest dependence between these parameters was identified for pine. While analyzing the relations of the crown density according to aerial photography and tree crowns closeness at the field survey, a weak relation was revealed.

The suggested variants to calculate a tree diameter are important to develop an automated algorithm to obtain the main taxation indicators by a remote tool, which allows determining the tree number, height and calculating the trunk diameter at $1.3 \mathrm{~m}$ level. It should be noted that determining the crown size (diameter - volume) according to LIDAR data may give an error due to shading of a crown part at a high stand density. The error also manifests itself when identifying trees with a height below 8 meters. At this stage, at implementing automated interpretation, the accuracy of determining the tree number, stand height and diameter is about $83.2 \%$.

\section{References}

1. N. P. Anuchin, Forest taxation (Moscow, Forest industry, 1982)

2. V. V. Zagreev, V. I. Sukhih, A. Z. Shvidenko, N. N. Gusev, A. G, Moshkalev, AllUnion standards for forest taxation: a reference book (Moscow, Kolos, 1992)

3. V. N. Minaev, S. V.Tetyukhin, V. F. Kovyazin, Forest taxation (St. Petersburg, SPbGLTA, 2004)

4. Manual on the allocation and taxation of cutting plots in forests of the Russian Federation, Approved by Order of the Federal Forestry Service of the Russian Federation no. 155 on June 15, Moscow (1993)

5. The scheme of territorial planning (an explanatory note): the project of the urban planning cadastre system of the Nefteyugansk District of KhMAO-Yugra (Omsk, Grad-Inform, 2007)

6. V. N. Shanin, M. P. Shashkov, N. V. Ivanova, P. Ya. Grabarnik, Russian Journal of Ecosystem Ecology, 4(1) (2016)

7. J.-L. Widlowski, M. Verstraete, B. Pinty, N. Gobron, Allometric relationships of selected European tree species: Parametrizations of tree architecture for the purpose of 3-D canopy reflectance models used in the interpretation of remote sensing data (European Commission, Joint Research Centre, Ispra (VA), Italy (2003))

8. J. Holmgren, M. Nilsson, H. Olsson, For. Sci., 49(3) (2003)

9. M. Maltamo, T. Tokola, M. Lehikoinen, For. Sci., 49(1) (2003)

10. J. E. Means, S. A. Acker, B. J. Fitt, M. Renslow, L. Emerson, C. J. Hendrix, Photogram. Eng. \& Rem. Sens., 66(11) (2000)

11. M. Näslund, Meddelanden fran Statens Skogsforskingsinstitut, 25 (1929)

12. J. E. S. Fransson, M. Magnusson, J. Holmgren, Estimation of forest stem volume using optical SPOT-5 satellite and laser data in combination, Proceedings of IGARSS 2004 Symposium, Science for Society. Anchorage, Alaska, 5, (2004)

13. J. Holmgren, Scandinavian Journal of Forest Research, 19 (2004)

14. N. Pinto, Mapping forest 3D structure with LIDAR and radar remote sensing (NASAJet Propulsion Laboratory, Pasadena, 2014)

15. A. I. Nikolaev, Proceedings of the Saint Petersburg Forestry Research Institute, $\mathbf{1}$ (2016) 